\title{
ANALISIS PENGARUH PEMBELIAN TERHADAP LOYALITAS DENGAN PERAN MODERASI KUALITAS PRODUK PADA KONUSMEN MINUMAN HYDRO COCCO
}

\author{
EDI SUKARJONO
}

Dosen Magister Manajemen Pascasarajana, Universitas Pamulang

\begin{abstract}
ABSTRAK
Penelitian ini merupakan kegiatan untuk mengetahui faktor yang mempengaruhi loyalitas pelanggan Hydro Cocco dengan peran moderasi variabel kulaitas produk. Saat ini, minat masyarakat untuk mengkonsumsi minuman berelektrolit semakin meningkat. Untuk hal itu, diperlukan pengkajian pada faktor yang berpengaruh pada loyalitas pelanggan. Fakta dilapangan menunjukkan bahwa masih banyaknya konsumen yang merasa kurang terpenuhi harapannya mengenai minuman berelektrolit. Tujuan penelitian adalah untuk mengkaji dan menganalisis besaran dari variabel penelitian berikut : (1) Kondisi : pembelian, kualitas produk, dan loyalitas konsumen, (2) Seberapa besar pengaruh pembelian terhadap loyalitas (4) Bagaimana peran moderasi dari variabel kualitas produk pada pengaruh pembelian terhadap loyalitas konsumen. Penelitian yang dilakukan adalah penelitian kuantitatif, dijabarkan dalam analisa deskriptif dan verifikatif dan dilakukan pada masyarakat di Tangerang. Teknik sampling yang digunakan aksidental sampling dengan ketentuan nasabah telah berlangganan setidaknya 3 tahun. Metode analisis data yang digunakan untuk menguji hipotesis penelitian kuantitatif ini adalah analisis regresi dengan peran moderator. Hasil penelitian menunjukkan bahwa responden : (1) Kondisi pembelian, kualitas produk, dan loyalitas pada kriteria kurang baik sampai dengan sangat baik. (2) Terdapat pengaruh yang positif dan signifikan dari pembelian terhadap loyalitas sebesar $63,70 \% 4)$ Terdapat peran moderasi dari variabel kualitas produk pada pengaruh dari pembelian terhadap loyalitas konsumen, dengan jenis moderator semua.
\end{abstract}

Kata Kunci : pembelian, kualitas produk, variabel moderator, loyalitas.

\section{PENDAHULUAN}

Bisnis berbagai jenis makanan dan minuman saat ini sudah sangat diminati oleh banyak pelaku bisnis, mulai dari skala home industry sampai pada pengusaha bertaraf internasional. Berbagai jenis minuman saat ini telah dipasarkan, dan para pelaku bisnis membuat konsep produk minuman dengan disesuaikan pada tipikal aktivitas dan atau kebutuhan konsumen seharihari. Hal ini tentunya untuk memudahkan dalam hal segemntasi dan positioning produk yang di produksi dalam pemasaran dan upaya penjualannya.

Salah satu yang sangat menarik untuk di simak adalah 
minuman yang mengandung elektrolit lengkap bagi kebutuhan tubuh. Sisi menarik dari produk ini adalah karena zat elektrolit diperoleh dari bahan herbal alami, yakni air kelapa. Hydro Coco merupakan meniuman berelektrolit yang disediakan dengan kelengkapan elektrolit yang telah mampu memenuhi kebutuhan elektrolit tubuh sehingga tubuh di harapkan tidak mengalami dehifrasi, setelah mengkonsumsinya sesuai dengan kebutuhan saat itu.

Sebagai salah satu produk yang diproduksi dan dipasarkan oleh perusahaan ternama, tidak menutup kemungkinan bahwa produk ini akan terdesak oleh adanya persaingan dengan produk lain dan tentunya dari perusahaan lain. Persepsi merek yang sudah begitu melegenda, baik yang tersemat pada produk maupun produsennya, mampu menjamin kebaerhasilan dalam upaya penetrasi pasar maupun perluasan pasar dari para tenaga marketing dan sales yang ditugaskan.

Dalam observasi dilapangan, menunjukkan bahwa untuk segmen tertentu telah mengenal dan mengkonsumsi produk tersebut dengan baik, bahkan dalam observasi lebih lanjut mereka pada umunya yakin dengan kualitas produk tersebut, namun relalitanya tidak sama pada segmen tertentu lainya. Disamping itu, pada umunya jarang ditemui adanya promosi produk teresebut pada media atau tempat yang sering digunakan untuk aktivitas populasi yang di observasi, dan sebagai akibatnya adalah bahwa produk tersebut tidak selalu menjadi pilihan utama oleh konsumen minuman berelektrolit.

Upaya utama bagi perusahaan yang telah memiliki daya sebar produk secara baik adalah pengikatan pelanggan dan bahkan sampai pada terbentuknya loyalitas pelanggan. Kelebihan pelanggan yang memiliki loyalitas adalah adanya spontanitas yang tinggi oleh konsumen untuk selalu mendapatkan dan memilih produk bersangkutan dalam memenuhi kebutuhannya, bahkan mereka yang telah loyal akan memiliki spontanitas baik dalam merekomndasikan produk kepada pihak yang berinteraksi dengannya. Loyalitas pelanggan bisa terbentuk dengan baik oleh kelengkapan estetika produk, yakni estetika dalam hal produk, estetika dalam hal ketenagaan, dan estetikan dalam hal industry yang meproduksinya. Estetika produk sangat berkaitan dengan manfaat dan rasa yang disediakan oleh produk serta desain kemasan dan kepraktisan kemasan untuk dibawa dan disimpan penggunanya.

Estetika ketenagaan meliputi tenaga yang merupakan sumber daya manuisa yang terlibat dalam transaksi produk baik langsung maupun tidak langsung keterlibatan secara langsung misalnya adalah bagaimana perilaku dan kecakan 
tenaga pemasaran maupun tenaga penjualan produk bersangkutan. Tenaga pemasaran meliputi tenaga yang melakukan pemasaran secara langsung kepada pihak yang terkait dalam perdagangan produk maupun tenaga yang bertugas sebagai pemain video iklan. Kualitas produk yang mampu merepresentasikan kebutuhan dan harapan konsumen dengan dukungan iklan ataupun promosi yang memadai akan sangat memiliki pengaruh yang sigifikan pada minat beli sehingga akan terbangun budaya loyal pada produk yang di pasarkan tersebut. Berdasar pada latar belakang masalah yang telah disusun tersebut, maka kegiatan penelitian ini menetapkan judul Analisis Pengaruh Pembelian terhadap Loyalitas dengan peran Moderasi Kualitas Produk Pada Konusmen Minuman hydro Cocco.

Manajemen penjualan akan berjalan dengan baik apa bila dilakukan berdasar pada perencaan kerja yang baik dalam mencapai target yang telah ditetapkan. Perencanaan pemberian target pada sales force merupakan bagian dari manajemen penjualan juga (Frans M Royan, 2011 : 36). Oleh karenanya, setiap individu yang masuk kedalam tim penjualan, harus memiliki semangat kerja secara parsial maupun simultan. Kemampuan bekerja secara parsial dari sebuah tim penjualan, akan sangat menjamin kemandirian kerja, sehingga akan mampu mengatasi masalah-masalah yang dihadapi. Masalah yang dihadapi setiap tenaga pejualan akan sangat berbeda antara satu tempat dengan tempat lainnya, oleh karena itu harus ada cara penyelesaian secara parsial. Disamping itu, semua anggota dalam tim penjualan harus mampu bergerak bersama secara simultan, harus saling mendukung antara satu dengan lainnya, karena pada akhirnya, akan keberhasilan penjualan harus merupakan keberhasilan tim kerja penjualan.

\section{METODOLOGI PENELITIAN}

Kegiatan penelitian ini dilakukan dengan menggunakan metode deskriptif verifikatif. Analisis deskriptif di lakukan untuk menggali fenomena dan kondisi yang riel dari obyek yang diteliti berdasar pada variabel yang telah ditetapkan. Hal tersebut selaras oleh apa yang sampaikan oleh Marzuki (2012:11) dalam Indra Setiawan : Penelitian deskriptif adalah penelitian yang menggambarkan kondisi obyek tanpa adanya hipotesis. Analisis secara verifikatif dilakukan untuk mengkaji dan menganalisis pengaruh dari variabel bebas terhadap veriabel terikat dan peran variabel moderasi. analisis pengaruh verivikatif ini juga dilakukan untuk mengetahui bagaimana pengaruh natar variabel diatas secara kuantitatif. Menurut Erlita (2016) : Sedangkan penelitian verifikatif bertujuan untuk menguji kebenaran hipotesis yang dilaksanakan melalui pengumpulan data di lapangan. 
a. Rancangan Pengujian Instrumen Penelitian

Pengujian instrument dilakukan dengan menggunakan metode uji validitas dan uji reliabilitas.

b. Rancangan Pengujian Asumsi Klasik

Pengujian asumsi klasik dilakukan dengan menguji normalitas data.

c. Rancangan Analisis data Analisis data dilakukan deskriptif dan verifikatif. Analisis deskriptif untuk mengkaji dan menganalisis kondisi obyek yang diteliti berdasar pada variabel yang ditetapkan. Sedangkan analisis verifikatif dilakukan untuk mengkaji dan menganalisis keterhubunggan secara kuantitatif dari variabel bebas terhadap variabel terikat dan peran dari variabel moderator.

d. Rancangan Pengujian Hipotesis. Pengujian hipotesis dilakukan dengan melihat nilai keterhubungan dan signifikansi dari nilai keterhubngan tersebut.

\section{HASIL DAN PEMBAHASAN}

Hasil penelitian adalah data yang diperoleh dari kuesioner yang telah disebar kepada populasi melalui sampel yang mewakilinya. Dalam peneltiian ini ditetapkan sampel sebanyak 100 responden. Dari data yang diperoleh, kemudian dilakukan pengujian, pengkajian dan analisis yang meliputi pengujian validitas dan reliabilitas data, pengkajian dan analisis deskriptif, pengujian dan analisis verifikatif.

Berdasar pada hasil pengujian validitas data, maka dapat disimpulkan bahwa semua instrument yang dipergunakan untuk pengambilan data pada semua variabel valid, karena semua nilai $r$ hitung pada pengujian lebih besar dari nilai $r$ tabel yang sebesar 2,276.

Berdasar pada hasil pengujian reliabilitas data, maka dapat disimpulkan bahwa semua instrument yang dipergunakan untuk pengambilan data pada semua variabel reliabel, karena semua nilai $r$ hitung pada pengujian lebih besar dari nilai $r$ tabel yang sebesar 0,221.

Pengujian data penelitian dilakukan dengan melihat normalitas data yang diuji. Berdasarkan hasil pengujian diperoleh petunjuk bahwa data penelitian yang diperoleh memenuhi syarat uji asumsi klasik normalitas data. Adapun hasil pengujian dapat dilhat sebagai berikut :

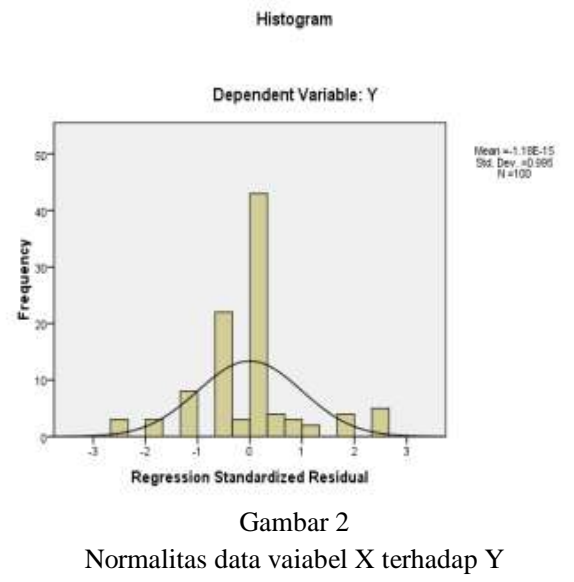




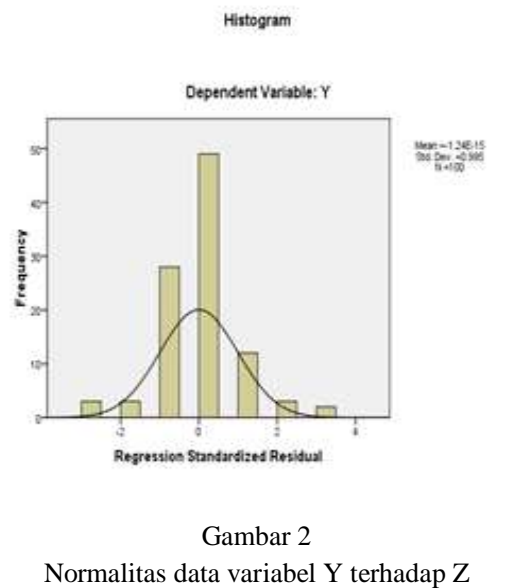

Sumber : Hasil pengolahan data

\section{Analisis Deskriptif}

Analisis deskriptif pada pelaporan hasil penelitian ini dilakukan untuk mengetahui kondisi obyek yang diteliti dengan mengkaji dan menganalisis opsi yang dipilih oleh responden pada instrument dari setiap variabel yang diteliti. Dengan menetapkan acuan kriteria berdasar rentang grade 4 / 5 atau 0,8 atau ada 5 grade, dengan pertimbangan pengukuran dengan skla likert dengan 5 opsi pilihan, dengan opsi 1 bernilai 1 dan opsi 5 bernilai 5 .

1) Analisis Kondisi Variabel Moderasi Kualitas Produk (M) Kriteria variabel bebas diperoleh dari opsi yang dipilih oleh responden dari kuesioner yang telah disebar. Adapun kriteria tersebaut dapat dilihat berikut ini :

Tabel 1. Tabel Kondisi Variabel Moderasi Kualitas Produk (M)

\begin{tabular}{|c|c|c|c|c|}
\hline $\begin{array}{l}\text { Pertanyaan } \\
\text { Variabel X }\end{array}$ & $\begin{array}{l}\text { Rata- } \\
\text { rata }\end{array}$ & $\begin{array}{l}\text { Standar } \\
\text { Deviasi }\end{array}$ & Nilai Riel & Kiteria \\
\hline Ke 1 & 3,991 & 0,424 & $3,567-4,415$ & $\begin{array}{l}\text { Baik sampai dengan sangat } \\
\text { baik }\end{array}$ \\
\hline Ke 2 & 3,922 & 0,486 & $3,436-4,408$ & $\begin{array}{l}\text { Baik sampai dengan sangat } \\
\text { baik }\end{array}$ \\
\hline Ke 3 & 3,713 & 0,537 & $3,176-4,250$ & $\begin{array}{l}\text { Kurang Baik sampai } \\
\text { dengan sangat baik }\end{array}$ \\
\hline $\operatorname{Ke} 4$ & 3,711 & 0,461 & $3,240-4,162$ & $\begin{array}{l}\text { Baik kurang baik samapai } \\
\text { dengan baik }\end{array}$ \\
\hline Ke 5 & 3,883 & 0,367 & $3,506-4,240$ & $\begin{array}{l}\text { Baik sampai dengan sangat } \\
\text { baik }\end{array}$ \\
\hline Ke 6 & 3,722 & 0,537 & $3,175-4,249$ & $\begin{array}{l}\text { Kurang Baik sampai } \\
\text { dengan sangat baik }\end{array}$ \\
\hline
\end{tabular}

Sumber : hasil pengolahan data

Berdasar pada Tabel 1 di atas, maka dapat di ketahui bahwa untuk pertanyaan ke 3 dan ke 6 memiliki kriteria kurang baik sampai dengan sangat baik. Sedangkan untuk pertanyaan nomor $1,2,4$, dan 5 memiliki kriteria baik sampai dengan sangat baik. Nilai kriteria paling rendah pada pertanyaan nomor 6 dan paling tinggi pada pertanyaan nomor 1. 
2) Analisis Kondisi Variabel Pembelian (Y)

Analisis kondisi variabel pembelian dilakukan dengan menganalisis angka kriteria yang dibuat berdasar opsi yang dipilih oleh responden. Adapun ktiteria tresebut bisa dilihat sebagaimana yang tercantum pada tabel dibawah ini :

Tabel 2. Tabel Kondisi Variabel Pembelian (Y)

\begin{tabular}{|l|r|r|r|l|}
\hline $\begin{array}{c}\text { Pertanyaan } \\
\text { Variabel Y }\end{array}$ & $\begin{array}{c}\text { Rata- } \\
\text { rata }\end{array}$ & $\begin{array}{c}\text { Standar } \\
\text { Deviasi }\end{array}$ & Nilai Riel & \multicolumn{1}{|c|}{ Kiteria } \\
\hline Ke 1 & 3.969 & 0.320 & $3.649-4.289$ & Baik-baik \\
\hline Ke 2 & 3.801 & 0.518 & $3.283-4.319$ & Kurang baik-sangat baik \\
\hline Ke 3 & 3.781 & 0.446 & $3.335-4.227$ & Kurang baik-Sangat baik \\
\hline Ke 4 & 3.909 & 0.321 & $3.588-4.230$ & Baik-sangat baik \\
\hline Ke 5 & 3.869 & 0.442 & $3.427-4.311$ & Baik-sangat baik \\
\hline Ke 6 & 3.712 & 0.456 & $3.256-4.168$ & Kurang baik-baik \\
\hline
\end{tabular}

Sumber : Hasil Pengolahan Data

Berdasar pada Tabel 2 di atas, instrument atau pertanyaan nomor maka dapat dianalisis bahwa kondisi pembelian berdasar pada instrument berada pada kriteria kurang baik sampai dengan sangat baik. Kriteria terendah ada pada instumen atau pertanyaan nomor 5 dan kriteria tertinggi ada pada instrument atau pertanyaan nomor 5. Disamping itu, dapat diketahui bahwa kriteria 2,3, dan 6 .

3) Analisis Kondisi Variabel Loyalitas (Y).

Kondisi dari variabel loyalitas (Y) di tetapkan berdasar pada kriteria yang dibaut beradasar opsi yang dipilih oleh responden, dan dapat dilihat berdasar pada tabel dibawah ini. kurang baik dijumpai pada

Tabel 3. Tabel Kondisi Variabel Loyalitas (Y)

\begin{tabular}{|l|r|r|r|l|}
\hline $\begin{array}{c}\text { Pertanyaan } \\
\text { Variabel Y }\end{array}$ & $\begin{array}{c}\text { Rata- } \\
\text { rata }\end{array}$ & $\begin{array}{c}\text { Standar } \\
\text { Deviasi }\end{array}$ & Nilai Riel & \multicolumn{1}{|c|}{ Kiteria } \\
\hline Ke 1 & 3.878 & 0.321 & $3.557--4.199$ & Baik \\
\hline Ke 2 & 3.809 & 0.518 & $3.291--4.327$ & Kurang baik-sangat baik \\
\hline Ke 3 & 3.859 & 0.446 & $3.413--4.305$ & Baik-Sangat baik \\
\hline Ke 4 & 3.768 & 0.321 & $3.447--4.089$ & Baik \\
\hline Ke 5 & 3.803 & 0.442 & $3.361--4.245$ & Kurang Baik-sangat baik \\
\hline Ke 6 & 3.848 & 0.456 & $3.392--4.304$ & Kurang baik-sangat baik \\
\hline
\end{tabular}

Sumber : Hasil pengolahan data

Berdasar pada Tabel 3 di atas, maka dapat di ketahui bahwa kriteria variabel loyalitas pelanggan (Y) berdasar pada instrument atau pertanyaan berada pada kondisi kurang baik samapai dengan sangat baik. Kriteria terendah ada pada ainstrumen atau pertanyaan nomor 2 
dan tertinggi pada pertanyaan nomor 3. Kritetia kurang baik secara keseluruhan ada pada instrument atau pertanyaan nomor 2,5, dan 6 .

\section{Analisis Verifikatif}

Analisis verifikatif dilakukan untuk mengetahui nilai pengaruh dari variabel bebas kualitas produk (X) terhadap variabel intervening pembelian (Y) dan peran moderasi variabel kualitas produk (M) pada pengaruh $\mathrm{X}$ terhadap $\mathrm{Y}$. Nilai keterhubungan dari variabel-variabel diatas di buat menjadi persamaan regresi dengan bambar model penelitian

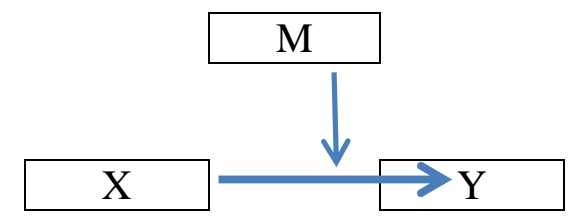

Adapun besaran angka dari nilai tersebut dapat diketahui berdasar tabel dibawah ini :

a. Pengaruh X terhadap Y

Tabel 4. Tabel Pengaruh Variabel Bebas terhaap ariabel terikat

\section{Coefficients $^{\mathrm{a}}$}

\begin{tabular}{|c|c|c|c|c|c|}
\hline \multirow[b]{2}{*}{ Model } & \multicolumn{2}{|c|}{$\begin{array}{c}\text { Unstandardized } \\
\text { Coefficients }\end{array}$} & \multirow{2}{*}{\begin{tabular}{|c|}
$\begin{array}{c}\text { Standardized } \\
\text { Coefficients }\end{array}$ \\
Beta \\
\end{tabular}} & \multirow[b]{2}{*}{$\mathrm{t}$} & \multirow[b]{2}{*}{ Sig. } \\
\hline & B & Std. Error & & & \\
\hline (Constant) & 3.514 & .616 & & 5.707 & .000 \\
\hline$X$ & .795 & .042 & .886 & 18.886 & .000 \\
\hline
\end{tabular}

a. Dependent Variable: Y

Sumber : Hasil pengolahan data

Berdasar pada tabel diatas, maka persamaan regresi sederhana yang terbentuk adalah

$\mathrm{Y}=3,514+0,886 \mathrm{X}+\mathrm{e}$

Hal tersebut menggambarkan bahwa:

a. Nilai konstanta 3,514, artinya adalah apabila tidak ada pertimbangan kualitas produk, maka telah terdapat nilai pembelian sebesar 3,514. Nilai tersebut signifikan, karena memiliki nilai $\mathrm{t}$ sig. 0,000 dan lebih kecil dari 0,005 atau $0,000<0,05$.

b. Nilai koefisien regresi sebesar 0,886, artinya adalah apabila terdapat perbaikan kondisi sebesar
1 unit pada variabel $\mathrm{X}$ maka secara otomatis akan terjadi perbaikan kondisi pada variabel Y sebesar 0,886 kali.

c. Nilai koefisien regresi e sebesar 1 $-0,886=0,114$

Sehingga persamaan akhir menjadi $\mathrm{Y}=2,668+0,863 \mathrm{X}+$ $0,137 \mathrm{e}$

d. Kemampuan model menjelaskan pengaruh $\mathrm{X}$ terhadap $\mathrm{Y}$

Kemampuan model menjelaskan penngaruh $\mathrm{X}$ terhadap $\mathrm{Y}$ dapat dilihat berdasar tabel berikut ini : 
Tabel 5. Tabel Model Summary Regresi Sederhana

Model Summary

\begin{tabular}{|l|l|r|r|r|}
\hline $\begin{array}{l}\text { Mode } \\
1\end{array}$ & $\mathrm{R}$ & $\mathrm{R}$ Square & $\begin{array}{c}\text { Adjusted } \mathrm{R} \\
\text { Square }\end{array}$ & $\begin{array}{c}\text { Std. Error of } \\
\text { the Estimate }\end{array}$ \\
\hline 1 & $.886^{\mathrm{2}}$ & .784 & .782 & 1.64349 \\
\hline
\end{tabular}

a. Predictors: (Constant), $X$

Sumber : Hasil pengolahan data

Tabel 6. Tabel F

ANOVA'

\begin{tabular}{|ll|r|r|r|r|r|}
\hline & & \multicolumn{1}{c|}{$\begin{array}{c}\text { Sum of } \\
\text { Squares }\end{array}$} & df & Mean Square & F & Sig. \\
\hline 1 & Regression & 963.444 & 1 & 963.444 & 356.693 & $.000^{2}$ \\
& Residual & 264.703 & 98 & 2.701 & & \\
& Total & 1228.147 & 99 & & & \\
\hline
\end{tabular}

a. Predictors: (Constant), $X$

b. Dependent Variable: $Y$

Sumber : Hasil pengolahan data

Berdasar pada tabel $4.5 \quad$ karena memiliki nilai $\mathrm{F}$ sig. sebesar model summary diatas diperoleh $0,000<0,05$.

nilai R Square sebesar 0,784 hal ini menjelaskan bahwa model yang di bentuk memiliki kemampuan menjelaskan pengaruh $\mathrm{X}$ terhadap $\mathrm{Y}$ sebesar 78,40\%. Nilai ini signifikan, a. Pengaruh $\mathrm{X}$ terhadap $\mathrm{Y}$ dan Peran Moderator Nilai pengaruh dari variabel $\mathrm{X}$ terhadap $\mathrm{Y}$ yang di moderasi oleh $M$ dapat di lihat sebagaimana tabel dibawah ini.

Tabel 7. Pengaruh Terahdap Variabel Loyalitas

Coefficients

\begin{tabular}{|c|c|c|c|c|c|c|}
\hline \multirow[b]{2}{*}{ Mode } & & \multicolumn{2}{|c|}{ Unstandardized Coefficients } & \multirow{2}{*}{$\begin{array}{c}\begin{array}{c}\text { Standardized } \\
\text { Coefficients }\end{array} \\
\text { Beta } \\
\end{array}$} & \multirow[b]{2}{*}{1} & \multirow[b]{2}{*}{ Sig. } \\
\hline & & $\mathrm{B}$ & Std. Error & & & \\
\hline \multirow[t]{4}{*}{1} & (Constant) & -.820 & 1.592 & & -.515 & .608 \\
\hline & $x$ & .717 & .129 & .798 & 5.538 & .000 \\
\hline & M & .808 & .189 & .915 & 4.268 & .000 \\
\hline & $M X$ & -.028 & .012 & -.749 & -2.408 & .018 \\
\hline
\end{tabular}

a. Dependent Variable: $Y$

Berdasar pada tabel 4.7 di atas, maka diperoleh persamaan regresi berganda sebagai berikut
$\mathrm{Y}=-0,820+0,798 \mathrm{X}+0,915 \mathrm{M}-$ $0,749 \mathrm{MX}+\mathrm{e}$

Artinya adalah 
a. Nilai konstanta $-0,820$ hal ini menggambarkan bahwa apa bila tidak ada pembelian, maka tidak akan timbul loyalitas, bahkan loyalitas memiliki nilai $-0,820$. Nilai tersebut tidak signifikan, sehingga pengolahan data harus dilanjutkan sampai pada tahap stepwise.

b. Nilai koefisien regresi X sebesar 0,915 hal ini meneggamabrkan bahwa apabila koefisien variabel moderator tetap, maka setiap perbaikan kondisi pembelian sebesar 1 unit akan terjadi perbaikan kondisi loyalitas sebesar 0,915 kali. Nilai ini signifikan karena memiliki nilai $\mathrm{t}$ sig $0,000<0,05$.

c. Nilai koefisien regresi $\mathrm{M}$ sebesar 0,915. Hal ini menggambarkan bahwa apa bila nilai koefisien regresi $\mathrm{X}$ tetap, maka setiap kali terdapat perbaikan kondisi 1 unit pada variabel moderator akan terjadi perbaikan kondisi loyalitas sebesar 0,915 kali.

d. Nilai koefisien regresi dari MX bernilai negatif atau $-0,749$. Hal ini menggambarkan bahwa variabel $\mathrm{M}$ memiliki peran memperlemah pengaruh dari $\mathrm{X}$ terhadap Y. Nilai tersebut signifikan, karena memiliki sig.t sebesar $0,018<0,05$.

e. Pengolahan data tahap stepwise Oleh karena ada nilai sig.t yang tidak signifikan, yakni nilai sig.t pada konstanta maka dilakukan pengolahan data sampai pada tahap stepwise dengan hasil sebagai berikut :

Tabel 8. Tabel Hasil Pengolahan Data Tahap Stepwise

\begin{tabular}{|c|c|c|c|c|c|c|}
\hline \multicolumn{7}{|c|}{ Coefficients ${ }^{\star}$} \\
\hline \multirow{2}{*}{\multicolumn{2}{|c|}{ Model }} & \multicolumn{2}{|c|}{ Unstandardized Coefficients } & \multirow{2}{*}{$\begin{array}{c}\begin{array}{c}\text { Standardized } \\
\text { Coefficients }\end{array} \\
\text { Beta } \\
\end{array}$} & \multirow[b]{2}{*}{$t$} & \multirow[b]{2}{*}{ Sig. } \\
\hline & & $B$ & Std. Error & & & \\
\hline \multirow[t]{2}{*}{1} & (Constant) & 7.493 & 410 & & 18.273 & .000 \\
\hline & MY & .034 & .002 & .889 & 19.196 & .000 \\
\hline \multirow[t]{3}{*}{2} & (Constant) & 5.312 & .744 & & 7.143 & .000 \\
\hline & MY & .018 & .005 & .482 & 3.830 & .000 \\
\hline & $\mathrm{x}$ & 389 & 113 & 434 & 3.442 & .001 \\
\hline \multirow[t]{4}{*}{3} & (Constant) & -.820 & 1.592 & & -.515 & .608 \\
\hline & MY & -.028 & .012 & -.749 & -2.408 & .018 \\
\hline & $x$ & .717 & .129 & .798 & 5.538 & .000 \\
\hline & $M$ & 808 & 189 & 915 & 4.268 & 000 \\
\hline
\end{tabular}

a. Dependent Variable: $Y$

Sumber : hasil pengolahan data

Berdasar pada tabel diatas maka dapat diperoleh model secara riel dengan nilai sig.t signifikan sebagaimana pada kolom kedua, $\mathrm{Y}=$ $5,312+0,434 \mathrm{X}+0,482 \mathrm{MX}+\mathrm{e}$ a. Pengujian Peran Moderator Pengujian dilakukan dengan membanding nilai $\mathrm{R}$ square pada tabel model summary tanpa moderator atau pada regresi sederhana dengan tabel model 
summary dengan adanya peran

berganda, sebagai berikut :

moderator atau pada regresi

Tabel 9. Model Summary Sederhana

\begin{tabular}{|l|r|r|r|r|}
\hline Model & $\mathrm{R}$ & R Square & $\begin{array}{c}\text { Adjusted R } \\
\text { Square }\end{array}$ & $\begin{array}{r}\text { Std. Error of } \\
\text { the Estimate }\end{array}$ \\
\hline 1 & $.886^{\mathrm{a}}$ & .784 & .782 & 1.64349 \\
\hline
\end{tabular}

a. Predictors: (Constant), X

Sumber : hasil pengolahan data

Tabel 10. Model Summary Regresi Berganda

\begin{tabular}{|l|r|r|r|r|}
\hline Model & R & R Square & $\begin{array}{c}\text { Adjusted R } \\
\text { Square }\end{array}$ & $\begin{array}{c}\text { Std. Error of } \\
\text { the Estimate }\end{array}$ \\
\hline 1 & $.918^{\mathrm{a}}$ & .843 & .838 & 1.41882 \\
\hline
\end{tabular}

a. Predictors: (Constant), MY, X, M

Sumber : hasil pengolahan data

Berdasar pada kedua tabel diatas, dapat diketahui bahwa nilai dari RSquare pada model summary regresi sederhana(tabel 4.9) < RSquare model summary regresi berganda (tabel 4.10) atau 0,784 < 0,783 . Sehingga dapat diambil keputusan bahwa produk berperan sebagai variabel moderator.

\section{Pengujian Jenis Variabel Moderator}

Pengujian peran dari moderator, apakah berperan sebagai moderator murni, moderator semu, atau bukan moderator dilakukan dengan langkah berikut :

a. Memeriksa nilai sig $t$ dari koefisien regresi $M$ pada tabel model summary tanpa peran interaksi MX (tabel 4.10) dengan koefisien regresi MX pada model summary yang memasukkan peran MX . (tabel 4.11)

b. Menetapkan keputusan

Apabila nilai sig.t dari kedua tabel signifikan maka dikatakan moderator penuh, apabila salah satu tidak signifikan merupakan modearator semu, dan bila keduanya tidak signifikan maka bukan moderator.

Adapun langkah tersebut dapat dilakukan sebagai berikut : Memeriksa nilai sig.t atau $t$ untuk variabel $\mathrm{M}$ pada tabel 4.11 dan nilai sig.t XM pada tabel 4.12. apakah keduanya signifikan, apakah salah satunya yang signifikan, atau keduanya tidak signifikan. Dikatakan signifikan apabila nilai sig.t $<0,05$. 
Tabel 11. Tabel Pengaruh dari Variabel X dan M terhadap Y

Coefficients ${ }^{3}$

\begin{tabular}{|c|c|c|c|c|c|c|}
\hline \multirow{2}{*}{\multicolumn{2}{|c|}{ Model }} & \multicolumn{2}{|c|}{ Unstandardized Coefficients } & \multirow{2}{*}{$\begin{array}{c}\begin{array}{c}\text { Standardized } \\
\text { Coefficients }\end{array} \\
\text { Beta } \\
\end{array}$} & \multirow[b]{2}{*}{$t$} & \multirow[b]{2}{*}{ Sig. } \\
\hline & & $B$ & Std. Error & & & \\
\hline \multirow[t]{3}{*}{1} & (Constant) & 2.779 & .562 & & 4.946 & .000 \\
\hline & $x$ & .457 & .074 & .510 & 6.214 & .000 \\
\hline & M & .385 & .072 & .436 & 5.319 & .000 \\
\hline
\end{tabular}

a. Dependent Variable: $Y$

Sumber : hasil pengolahan data

Sedangkan tampilan dari tabel 4.12 adalah sebagai berikut :

Tabel 12. Tabel Pengaruh X,M, dan MX terhadap Y

\begin{tabular}{|c|c|c|c|c|c|c|}
\hline \multicolumn{7}{|c|}{ Coefficients ${ }^{2}$} \\
\hline \multirow{2}{*}{\multicolumn{2}{|c|}{ Model }} & \multicolumn{2}{|c|}{ Unstandardized Coefficients } & \multirow{2}{*}{$\begin{array}{c}\begin{array}{c}\text { Standardized } \\
\text { Coefficients }\end{array} \\
\text { Beta } \\
\end{array}$} & \multirow[b]{2}{*}{$\mathrm{t}$} & \multirow[b]{2}{*}{ Sia. } \\
\hline & & B & Std. Error & & & \\
\hline \multirow[t]{4}{*}{1} & (Constant) & -.820 & 1.592 & & -.515 & .608 \\
\hline & $x$ & .717 & .129 & .798 & 5.538 & .000 \\
\hline & M & .808 & .189 & .915 & 4.268 & .000 \\
\hline & $\mathrm{MX}$ & -.028 & .012 & -.749 & -2.408 & .018 \\
\hline
\end{tabular}

a. Dependent Variable: $Y$

Berdasar pada kedua tabel diatas, dapat diketahui bahwa nilai sig.t dari koefisien regresi $\mathbf{M}$ tabel pertama signifikan dan nilai sig.t koefisien regresi MX juga signifikan, sehingga dapat diputuskan bahwa produk berperan sebagai moderator semu atau dengan kata lain bisa diperankan sebagai variabel bebas bisa juga diperankan sebagai variabel moderator.

\section{Pengujian Hipotesis}

1) Pengujian hipotesis pengaruh $X$ terhadap Y

Tabel 13. Tabel Pengujian Hipotesis Pengaru dari Variabel X terhadap Y

\begin{tabular}{|l|l|l|l|}
\hline $\begin{array}{l}\text { Nilai } \\
\text { pengaruh }\end{array}$ & Sig.t & $\begin{array}{l}\text { Taraf } \\
\text { kepercayaan }\end{array}$ & Keputusan \\
\hline $\begin{array}{l}(0,798)^{2}= \\
0,637\end{array}$ & 0,000 & 0,05 & $\begin{array}{l}\mathrm{H}_{0} \text { ditolak, terdapat pengaruh } \\
\text { yang positif dan signifikan. }\end{array}$ \\
\hline
\end{tabular}

Sumber : Hasil pengolahan data

2) Pengujian hipotesis peran moderasi $M$ pada pengaruh $X$ terhadap $Y$

Tabel 14. Tabel Pengujian Hopotesisi Peran Moderasi Variabel Kualitas Produk

\begin{tabular}{|l|l|l|}
\hline $\begin{array}{l}\text { R Square Regresi } \\
\text { sederhana }\end{array}$ & $\begin{array}{l}\mathrm{R} \quad \text { Square } \\
\text { Regresi } \\
\text { berganda }\end{array}$ & Keputusan \\
\hline
\end{tabular}




\begin{tabular}{|l|l|l|}
\hline 0,784 & 0,843 & $\begin{array}{l}\mathrm{H}_{0} \text { ditolak, terdapat peran moderasi } \\
\text { variabel produk pada pengaruh } \\
\text { variabel } \mathrm{X} \text { terhadap variabel Y }\end{array}$ \\
\hline
\end{tabular}

Sumber : hasil pengolahan data

\section{Pembahasan Deskriptif}

$$
\text { Pembahasan deskriptif }
$$

dilakukan dengan membahas kondisi dari variabel pembelian, kualitas produk, dan loyalitas berdasar pada pilihan terhadap opsi jawaban yang disediakan. Dari opsi yang dipilih kemudian ditentukan skor kriteria sangat tidak baik, tidak baik, kurang baik, baik, dan sangat baik.

1) Kondisi Variabel Porduk (M)

Kondisi variabel produk berada pada rentang kriteria kurang baik sampai dengan sangat baik. Kriteria kurang baik ada pada pertanyaan Anda merasa cocok dan menikmati semua varian rasa minuman hidro coco dengan skor kriteria 3,176 dan pertanyaan Hidro coco selalu bisa menjaga kondisi tubuh Anda tetap segar dalam waktu lebih lama dengan skor kriteria 3,175 . Dengan fakta tersebut, maka dapat ditemukan masukan dari populasi bahwa minuman hidro cocco memiliki varian rasa yang kurang digemari oleh konsumen. Dalam penelitian ini, belum diketahui varian rasa apa yang kurang digemari oleh konsumen. Namun demikian, telah menjadi realita bahwa pihak produsen harus menggali lebih dalam di lapangan, sebenarnya varian apa yang kurang digemari, dan selanjutnya juga sekalian bisa melakukan survey terhadap usulan varian rasa yang sekiranya digemari.

Pada observasi dilapangan, diperoleh petunjuk bahwa minuman hydro cocco rasa gula merah dan rasa vanilla bisa dijadikan bahan pertimbangan untuk di produksi dan dipasarkan. Varian rasa gula merah atau gula aren terasa lebih menyatu, mengingat keduanya berasal dari pohon yang sama dengan air kelapa. Disamping itu, gula kelapa saat ini telah menjadi menu kudapan di berbagai daerah Indonesia, sehingga varian rasa tersebut dapat dengan mudah bisa diterima masysarkat.

2) Kondisi Variabel Pembelian (X)

Kondisi variabel pembelian berada pada kriteria kurang baik sampai dengan sangat baik. Kriteria kurang baik ada pada pertanyaan Anda merasa bahwa komposisi pada produk minuman hidro coco menarik minat Anda untuk membeilinya dengan nilai kriteria 3,283; Anda merasa tertarik dengan aneka rasa dari produk minuman hidro coco dengan nilai kriteria 3,335; dan Isi / materi iklan dan media iklan hidro coco mampu membuat Anda lebih memilih hidro coco dengan nilai kriteria 3,256.

Pada saat ditanyakan mengenai apakah komposisi menjadi daya tarik pembeli, ternyata tidak semua konsumen mampu memiliki pemahaman mengenai komposisi. Oleh karenanya pada pembuatan 
iklan, kelebihan dari komposisi hydro cocco harus lebih diperjelas dan ditonjolkan. Langkah ini harus di wujudkan, agar kedepan keunggulan dari komposisi dan bahan baku minuman hydro cocco bisa menjadi nilai tambah dan menjadi nilai kompetitif produk.

Varian rasa dari minuman hydro cocco tidak selalu menjadi nilai tambah menurut pendapat populasi yang diteliti. Hal ini memberikan petunjuk bagi produsen untuk menambah varian rasa yang lebih menyatu dengan rasa air kelapa. Hydro cocco rasa jeruk sepertinya menjadi salah satu varian rasa yang kurang menyatu dengan kealamian air kelapa bagi sebagian konsumennya. Oleh karena itu, pengemambangan varian rasa yang lebih menyatu dengan kealamian rasa air kelapa harus segera di produksi dan dipasarkan, sehingga akan memeperbaiki kondisi pembelian dan atau minat pembelian oleh konsumen.

Iklan hydro cocco tidak lagi mejadi alasan bagi konsumen untuk membali produk tersebut. Hal ini bisa disebabkan bahwa persepsi merek sudah baik. Namun demikian, bisa juga karena konten dan media iklan tidak lagi terbiasa ditemukan oleh konsumen bersangkutan. Untuk lebih meningkatkan kondisi pembelian oleh konsumen, maka akan lebih baik apabila dilakukan pembenahan pada perihal konten dan media iklan yang lebih update.
3) Kondisi Variabel Loyalitas (Y)

Kondisis variabel loyalitas berada pada rentang kurang baik sampai dengan dangat baik. Kriteria kurang baik ada pada pertanyaan Anda selalu merasa lebih tepat minum hidro coco saat banyak berkeringat dengan nilai kriteria 3,291; Anda tidak keberatan dengan adanya penyesuaian harga untuk menyesuaian keadaan penjualan 3,361; Anda memiliki kebiasaan atau sering menyarankan teman atau saudara untuk lebih memilih minuman hidro coco saat sedang berkeringat berlebihan 3,392.

Pada saat berkeringat, populasi yang diteliti merasa tidak selalu memilih minuman hydro cocco. Hal ini bisa saja disebabkan oleh karena produsen belum optimal dalam melakukan penetrasi pasar, sehingga pada saat dibutuhkan produk tersebut tidak selalu ada pada jangkauan konsumen yang memerlukannya. Di sisi lain, bisa saja karena berkeringat memerlukan minum yang banyak, sedangkan kemasan hidro cocco hanya memiliki 1 ukuran kemasan, sehingga tidak ada pilihan yang lebih banyak volumenya, disamping juga kesulitan bagi konsumen untuk menyimpan selagi minuman belum habis, karena memang bentuk kemasan yang kurang mendukung. Oleh karenanya, di massa kedepan, hendaknya di pasarkan juga varian produk dengan isi yang lebih banyak dan kemasan yang bisa dengan mudah di buka 
tutup dan mudah di bawa beraktifitas.

Harga masih menjadi salah satu kendala bagi populasi penelitian. Hal ini ditunjukkan oleh pertanyaan Anda tidak keberatan dengan adanya penyesuaian harga untuk menyesuaian keadaan penjualan yang mendapatkan nilai kriteria 3,361 atau kurang baik. Maksudnya adalah bahwa perubahan harga masih menjadi hal sensitive bagi sebagian anggota populasi yang diteliti. Untuk itu, apabila akan dilakukan penaikan harga, harus dengan kebijakan yang lebih terhindar dari resistensi konsumen.

Loyalitas pelanggan menjadi salah satu perihal yang harus diperhatikan oleh produsen. Hal ini menyikapi jawaban sebagian responden yang kurang berminat untuk mereferensikan produk ini kepada orang-orang terdekat konsumen. Untuk kedepan, diperlukan kiat agar konsumen lebih memiliki rasa fanatic terhadap keunggulan kompetitif dari merek produk, sehingga minat mereferensikan akan menjadi spontanitas bagi anggota populasi yang diteliiti.

\section{Pembahasan Verifikatif}

Pembahasan verifikatif
bertujuan untuk membahas keterhubungan antar variabel yang diuji secara kuantitatif. Pembahasan meliputi besaran pengaruh dari variabel pembelian terhadap loyalitas dan peran moderator dari variabel kualitas produk pada pengaruh dari pembelian terhadap loyalitas.

1) Pengaruh variabel pembelian

terhadap loyalitas pelanggan

Pengaruh dari variabel pembelian terhadap loyalitas sebesar $63,70 \%$. Besaran pengaruh ini signifikan, karena memiliki nilai sig.t $0,000<0,050$. Besar nilai pengaruh ini tentunya belum optimal, sehingga memerlukan adanya upaya optimalisasi. Strategi peningkatan nilai pengaruh ini bisa dilakukan terutama berdasar pada item pertanyaan yang masih memiliki kriteria kurang baik. Harus dilakukan penelaahan dan observasi untuk selanjutnya diteruskan dengan penelitian lebih seksama untuk mengetahui penyebab dari masih kurang baiknya kriteria tersebut.

Apabila kriteria tersebut berhasil ditingkatkan menjadi baik atau bahkan sangat baik, maka secara otomatis akan terjadi peningkatan kondisi variabel. Perbaikan kondisi atau oeningkatan kondisi dengan sendirinya juga akan disertai peningkatan kondisi loyalitas, atau dengan kata lain, semakin baiknya kondisi variabel pembelian akan serta merta diikuti oleh semakin baiknya kondisi loyalitas.

Penelitian lebih lanjut hendaknya juga dilakukan dengan menetapkan variabel lain yang belum ditetapkan dalam model penelitian ini. Disamping itu, penetapan dimensi, penetapan indikator, atau penetapan pertanyaan juga bisa 
dipikirkan kembali. Pemikiran bisa mengarah pada upaya memperbanyak jenis atau mengganti dari apa yang sudah ada.

2) Peran moderasi variabel kualitas produk pada pengaruh pembelian terhadap loyalitas

Variabel kualitas produk memiliki peran moderasi pada pengaruh dari variabel pembelian terhadap loyalitas. Hal ini dibuktikan dengan semakin meningkatnya nilai pengaruh setelah variabel moderator dilibatkan. Namun demikian, mengingat jenis variabel moderator berdasarkan pengujian adalah moderator semu, maka akan lebih baik apabila variabel moderator ini untuk di fungsikan sebagai variabel bebas ke dua. Hal ini menimbang pada nilai koefisien korelasi dari interaksi variabel bebas dan variabel moderator yang memiliki nilai negatif dan signifikan.

\section{KESIMPULAN}

1. Kondisi variabel pembelian dalam kriteria kurang baik smapai dengan sangat baik, kondisi variabel moderator kualitas produk berada pada rentang kriteria kurang baik sampai dengan sangat baik, serta kondisi variabel loyalitas berada dalam rentang kriteria kurang baik sampai dengan sangat baik.

2. Terdapat pengaruh yang positif dan signifikan dari pembelian terhadap loyalitas pelanggan dengan besar pengaruh $63,70 \%$ dan pengaruh variabel diluar model yang ditetliti sebesar $36,30 \%$.

\section{REFRENSI}

Setiawan, Indra. (2006). Analisis

Strategi Pemasaran Dalam

Meningkatkan Volume

Penjualan Pada PT Versacon Medical"(Study Kasus di PT. Versacon Medical).Tesisi, Program Pascasarjana, Universitas Pamulang, Tangerang Selatan.

Erlita, Citra. (2016). Perusahaan Dan Tarif Premi Terhadap Minat Beli Yang Berdampak Pada Kepuasan Pelanggan, Tesis Program Pascasarjana, Universitas Pamulang, Tangerang Selatan.

Frans, M Royan. (2011). Menjadi Penjual Profesional Ala Sun Tzu, Kanisius.

Kotler dan Amstrong. (2003). Dasardasar Pemasaran, Jakarta : Indeks. 